'groups' and is also observed in vitro when galactose is added to intestinal slices. In view of the fact that glucose and galactose are mutually inhibitory with regard to their transport across the intestine, competitive inhibition of amino-acid transport by galactose seems unlikely as one would then expect glucose to inhibit as well. One could argue that either the transport of the hexoses or their phosphorylation in the intestinal cell might result in a drop in the mucosal levels of adenosine triphosphate (ATP). We measured ATP levels in intestinal slices of rats fed 30 per cent galactose and in controls. The mean ATP level in the galactose-fed rats was $0.492 \mu \mathrm{moles} / \mathrm{g}$ and in the controls $0.637 \mu$ moles/g $(P<0 \cdot 05)$. While these results are significant and of interest they do not allow us to conclude that the decrease in ATP levels is primarily involved in the impairment of amino-acid transport. Since phosphorylation of galactose and fructose occurs in the intestine and since phosphorylated sugars may inhibit enzymes such as phosphoglucomutase ${ }^{1}$, the accumulation of hexose phosphates may also be a factor in the derangement of amino-acid transport.

The precise mechanism for the inhibiting effect of galactose on amino-acid transport remains to be determined. However, on the basis of the investigations presented, it would appear likely that in the human disorder of galactosaemia there may be a defect in the transport of amino-acids not only in the kidney but also in the intestine.

This work was supported by grant $A M-01392$ from the National Institutes of Health.

Stuart J. Saunders * KuRt J. Isselbacher

Department of Medicine,

Harvard Medical School and

Medical Services (Gastrointestinal Unit),

Massachusetts General Hospital, Boston, Mass.

* U.S. Public Health Service InternationaliPost-doctoral Research'Fellow.

${ }^{2}$ Isselbacher, K. J., in The Metabolic Basis of Inherited Disease, first ed. (McGraw-Hill, New York).

Rosenberg, L. E., Weinberg, A. N., and Segal, S., Biochim. Biophys. Acta, 48, 500 (196i).

'Segal, S., Thier, S., Fox, M., and Rosenberg, L., Biochim. Biophys. Acta 65, 507 (1962)

'Rosenberg, L. E., Blair, A., and Segal, S., Biochim. Biophys. Acta, 54, $479(1961)$.

${ }^{5}$ Newey, H., and Smyth, D. H., Nature, 202, 400 (1964).

\section{Inhibitory Effect of Progesterone on the Activity of Human Myometrial Actomyosin Adenosinetriphosphatase}

IN the previous communication ${ }^{1}$ from this laboratory it was noted that progesterone in concentrations of more than $10 \mu \mathrm{g}$ (and up to $50 \mu \mathrm{g}$ tested) per mg wet weight human non-pregnant myometrial tissue inhibits the human myometrial ATPase activity on an average of 27.3 per cent $(P<0.001)$ based on fifteen experiments. On the other hand, oestradiol in fourteen cases in similar concentrations as for progesterone showed only an average reduction of 5.8 per cent $(P<0.01)$ on ATPase activity ${ }^{2}$.

In order to make sure that this inhibitory effect of progesterone is not entirely on the non-actomyosin fraction of the homogenate, actomyosin was extracted using $0.5 \mathrm{M}$ potassium chloride and ATP according to the procedure described by $\mathrm{Csapo}^{3}$. The ATPase activity of the human myometrial actomyosin was determined according to the procedure deseribed before ${ }^{1}$. The amount of inorganic phosphorus liberated/mg nitrogen actomyosin min at $37^{\circ} \mathrm{C}$ was taken as a measure of ATPase activity. The results of eleven non-pregnant and three pregnant human samples are shown in Table 1 .
Table 1

\begin{tabular}{|c|c|c|}
\hline $\begin{array}{l}\text { Average } \\
\text { liberate }\end{array}$ & $\begin{array}{l}\text { noles of phosphorus } \\
\text { ng } \mathrm{N}_{8} \text { actomyosin/ } \\
\text { incubation }\end{array}$ & \multirow{2}{*}{$\begin{array}{c}\text { Average } \\
\text { reduction in } \\
\text { phosphorus } \\
\text { liberated }(\mu \mathrm{moles})\end{array}$} \\
\hline Control & $\begin{array}{l}\text { Progesterone } 7 \cdot 46 \mathrm{vl} \\
\text { mg } \mathrm{N}_{1} \text { actomyosin }\end{array}$ & \\
\hline $\begin{array}{l}0.092 \\
0.047\end{array}$ & $\begin{array}{l}0.074 \\
0.034\end{array}$ & $\begin{array}{l}0.018(19 \cdot 6 \%)^{*} \\
0.013(27.6 \%)\end{array}$ \\
\hline
\end{tabular}

3 pregnant

$* t=5 \cdot 13$
$P<0 \cdot 001$

In conclusion it can be said, based on the results described, that progesterone has a definite inhibitory effect on the human myometrial actomyosin ATPase activity.

This work was supported in part by grant $H D$ 00524-4 from the U.S. Public Health Service.

\section{Kumar \\ P. R. ADAMS \\ A. C. BARNES}

Department of Gynaecology and Obstetrics,

the Johns Hopkins University School of Medicine and Hospital,

Baltimore, Maryland.

${ }^{1}$ Kumar, D., Adams, P. R., and Barnes, A. C., Nature, 208, 83 (1964).

'Kumar, D., Adams, P. R., and Barnes, A. C. (unpublished data),

${ }^{3}$ Csapo, A., Amer. J. Physiol., 160, 46 (1950).

\section{Binding of Thyroxine and Triiodothyronine by Heart and Pituitary Proteins}

The presence of thyroxine-binding activity in extracts of muscle tissues ${ }^{1}$ and in extracts of mouse thyrotropic and mammotrophic pituitary tumours ${ }^{2}$ has been demonstrated by observing the migration of radioactive thyroxine with the proteins in question during electrophoresis on paper at $p H \mathbf{H} \cdot 6$. The work recorded here on the relative affinity of water-soluble human heart and pituitary proteins for thyroxine $\left(T^{\prime} 4\right)$ and triiodothyronine (T3) made use of an independent binding assay.

The tissues were selected at autopsy, which was per. formed no later than $2 \mathrm{~h}$ after death. Every effort was made to obtain heart muscle and pituitary tissue that seemed to be unaffected by disease. (Death in all cases was associated with cancer.) The tissues were chilled immediately after collection, and were kept at $4^{\circ} \mathrm{C}$ throughout preparation. Pooled samples were used in all experiments.

Protein fractions were prepared by homogenizing small pieces of water-washed tissues from which visible fat and fibre had previously been removed. About $5 \mathrm{ml}$. of water was used per $\mathrm{g}$ of tissue homogenized. Insoluble material was separated by centrifugation and discarded.

In order to remove any $T 4$ or $T 3$ bound to the tissue proteins, each supernatant of about $50 \mathrm{ml}$. was dialysed at $4^{\circ} \mathrm{C}$ in a collulose casing against two 6-1. changes of distilled water, one 6-1. change of $0.05 \mathrm{M}$ acetic acid $(p H$ $3 \cdot 0$ ), and another two 6-l. changes of distilled water. Acetic acid was used in the dialysis procedure in order to enhance the separation of $T 4$ and $T 3$ from the proteins.

Some material precipitated during dialysis and this material was removed by centrifugation, leaving the water-soluble proteins in the supernatant. The latter was dried by lyophilization. Approximately $1 \mathrm{~g}$ of protein was recovered from each $100 \mathrm{~g}$ of heart muscle, and up to $10 \mathrm{mg}$ from each pituitary gland.

Before any binding investigation was made, each tissue preparation was tested for the presence of iodine by use of the ceric sulphate-arsenious acid reagent ${ }^{3}$, and was found to be negative. The tissue preparations were checked for contamination with serum proteins by electrophoresis on paper at $p \mathbf{H} \mathbf{8 . 6}$ in the presence of radioactive $T 4$. No radioactivity was found in the inter- $\alpha$ or albumin zone, and this result was interpreted as proof of the absence of serum proteins. 